\title{
Erratum to: Tracing Rhetoric and Material
}

\section{Life}

\author{
Bridie McGreavy, Justine Wells, George F. McHendry, Jv. \\ and Samantha Senda-Cook
}

Erratum to:

B. McGreavy et al. (eds.), Tracing Rhetoric and Material Life, Palgrave Studies in Media and Environmental Communication, https://doi.org/10.1007/978-3-319-65711-0

In the original version of the book, in the affiliation of "B. McGreavy", university name "Creighton University" has been changed as "University of Maine" in Chapters 1 and 4.

The updated online version for this book can be found at https://doi.org/10.1007/978-3-319-65711-0_1 https://doi.org/10.1007/978-3-319-65711-0_4 https://doi.org/10.1007/978-3-319-65711-0

(C) The Author(s) 2018 El

B. McGreavy et al. (eds.), Tracing Rhetoric and Material Life, Palgrave Studies in Media and Environmental Communication, https://doi.org/10.1007/978-3-319-65711-0_14 